\title{
The Missing Narratives: Exploring the Experiences of Malaysian Journalists and Family Members and Friends of Victims during the MH370 Aviation Crisis
}

\author{
Lim Shiang Shiang ${ }^{1 *}$, Ihediwa Samuel Chibundu ${ }^{1}$ and Sharon Wilson ${ }^{2}$ \\ ${ }^{1}$ Faculty of Arts and Social Science, Universiti Tunku Abdul Rahman, 31900 Kampar, Perak, Malaysia \\ ${ }^{2}$ Faculty of Creative Industries, Universiti Tunku Abdul Rahman, 43000, Kajang, Selangor, Malaysia
}

\begin{abstract}
The MH370 crisis which attracted global attention is considered one of the most perplexing disasters in aviation history by aviation experts. One of the highlights of the crisis was the alleged inability of Malaysian journalists to provide accurate information on the issue. Maximum news coverage, commentaries, expert views, and researches were carried out regarding the issue. However, most of them only focused on how Malaysian authorities handled the crisis. None ventured into Malaysian journalists' perspectives particularly on their concerns regarding their coverage of the crisis. Therefore, this study seeks to investigate the perspectives of journalists from the selected newspapers on their framing of the crisis, the alleged inconsistencies in their coverage, and the perceived lack of access to information. By giving journalists a voice to express their views on their performance, it is hoped that will deepen knowledge and understanding of the dynamics of press freedom, ownership, and control in the country. Through qualitative data analysis, the study found that MH370 news frames were greatly influenced by both internal and external factors, ranging from individuals to state levels. They include lack of experience in aviation news coverage on the part of the local Malaysian journalists; the internal gatekeeping process by the news editors of various newspapers which tend to

ARTICLE INFO

Article history:

Received: 17 December 2020

Accepted: 15 March 2021

Published: 30 June 2021 undermine the work of journalists; and the seen and unseen restrictions experienced by journalists and media houses at the state level.
\end{abstract}

DOI: https://doi.org/10.47836/pjssh.29.2.24

E-mail addresses:

Shiang2lim@gmail.com (Lim Shiang Shiang)

ihediwa@utar.edu.my (Ihediwa Samuel Chibundu)

Sharon@utar.edu.my (Sharon Wilson)

* Corresponding author

Keywords: Aviation crisis, crisis reporting, framing, journalists, MH370, press freedom 


\section{INTRODUCTION}

A Beijing-bound MH370 mysteriously disappeared from air traffic controllers' radar screens on March 8, 2014, without a trace. This incident triggered an unprecedented international search effort that involved more than 25 countries, including the United States of America, New Zealand, India, Vietnam, Singapore, and China (BBC News, 2014). At various points in time, hot discussions on what might have happened to MH370 emerged - possible scenarios include a mid-air explosion, a pilot suicide, or even a hijack by unknown perpetrators who tried to steal the airplane to an unknown location and flew 5,000 feet above the water to avoid military radar detection (Sorensen, 2014).

However, investigators have yet to make any formal announcement regarding the cause and the person responsible for the incident (Gavin, 2018). The fact that debris was found in different places around the world has raised more questions than answers. Beh (2018) mentioned in his report that most of the Chinese victims' families are not satisfied with the outcome of the investigation and have demanded the search and rescue be continued until there is a conclusive finding. A recent theory suggests that the plane was flown in a certain way to avoid detection before the pilot deliberately crashed it into the Southern Indian Ocean (Gavin, 2018). There is also a theory that a hacker (Randall, 2018) had somehow managed to hack into the flight software and hijacked the plane to a mysterious location.
Throughout the investigation and search for the missing flight many parties, especially the victims' families, have sharply criticized the airline and Malaysian government for their responses and actions (Daily Mail Online, 2015). A number of foreign newspapers blamed the Malaysian government for its failure to identify the sudden change of flight path from the radar data, mishandling of the crisis while providing false leads, unconfirmed facts, and missing details which have delayed and exacerbated the searching process (Secret China Online News, 2014). Nevertheless, some of the local newspapers reported that the greatest efforts have been provided and shown by the Malaysian authorities in investigating and tracking the flight (Utusan Online, 2015). Sankaran (2016) pointed out that international media produced more critical reports compared to the national media that produced more supportive reports.

Newspapers play a vital role in reporting crisis as it has the right in selecting and deciding what to be focused on and highlighted (Seon-Kyoung \& Karla, 2009). The way journalists frame the headlines and news stories could directly shape readers' perceptions of the MH370 incident and it could have a strong impact on Malaysia's reputation. Hence, it is essential to understand the meaning of journalism and the roles of journalists during a time of crisis.

This research attempts to explore the Malaysian journalists' experience in covering crisis with specific reference to 
the crisis involving Malaysian Airlines Flight MH370. It also seeks to investigate the internal and external factors that affected media framing in the coverage of the MH370 crisis. These will help us understand the extent to which the media has fulfilled its roles as an information provider, the kind of information that was disseminated, and whether it was enough for the people to react and respond to the crisis. Besides, the process of gathering and reporting the issue from the journalists' perspective would enhance the findings on what roles the media played during the crisis.

\section{LITERATURE REVIEW}

\section{Framing Aviation Crisis}

Crises threaten us on all sides. It may happen in a "specific, unexpected, and non-routine event or series of events that create high levels of uncertainty and threaten or are perceived to threaten high priority goals" (Seeger et al., 2003, pp. 204-205). The concept of crisis is often related to keywords such as "unrest", "conflict", "revolution" and "uncertainties" (Koselleck, 2006), "catastrophic (Filippini, 2017), and "threat" (Jacques, 2014).

With today's advanced aeronautical technology, transportation via airplane should be the safest among other transport modes (Li et al., 2015). However, catastrophic aviation incidents cannot be avoided. Despite the relative infrequency of these incidents, the aviation crisis has often caused strong public reactions and concerns, particularly social panic and riskavoiding behavior that is complicated by major social-political, and economic factors (Romantan, 2005). This could be observed through media frames which often contain certain ideological parameters.

In a study of aviation crisis, Entman (1991) mentioned that in the framing of Korean Airlines Flight 007 (KAL 007) that was shot down by the Soviet Union and Iran Air Flight 655 (IR655) that was shot down in its own country by the U.S. Navy's cruiser, reports on the KAL007 crisis emphasized on Soviet guilt and the act being morally indefensible while those on the IR655 crisis focused on the complexity of operating military-grade advanced technology. Even though both cases are rather similar, Entman indicated that U.S. media practitioners relied heavily on elite sources in covering both incidents, thus most frames were found to have supported the dominant frame as the elites were the "primary sponsor of news frames" (Entman, 1991, p.7). The contrasting frames embedded in these similar cases implied a reciprocal relationship between the media frame and the dominant frame, particularly government policies and media ownership.

Similarly, Yan and Kim (2015) found out that in the framing of the 2013 Asiana Airlines crash, United State newspapers attributed to pilot's responsibility. The scholars indicate that the United States and Korean newspapers use a negative slant toward each other while China media supported the United State frame but were slightly less negative compared to United State media. This reveals the link between crises with ongoing elite agendas which 
color different international media frames. Besides that, it also proves that the ruling class has the power to intervene in the frame-building process.

In analyzing the news frame of MH370, Park et al. (2016) found that the English newspaper The New Straits Times focused more on the local conflict frame, while the Chinese newspaper China Daily focused more on the human interest frame. In their news reports, The New Straits Times tends to frame the crisis for the sake of the Malaysian people by advocating for the casualties and mentioning possible solutions for conflict. On the other hand, China Daily focused on the Chinese perspectives by emphasizing the stories of the Chinese casualties and their families. The scholars further mentioned that both newspapers supported their own country's policy by framing the incident from the perspective of their own country. However, the study did not include interviews with media practitioners about the way journalists frame a crisis. Therefore, this study aims to fill the gap by conducting an in-depth interview with journalists of the selected news media. This is to further explore the coverage of the MH370 crisis as well as the level of information access during the crisis.

\section{Journalism and Crisis Reporting in Malaysia}

Journalists have the responsibility to act as checks and balances to ensure that there is transparency and accountability on the government's part. This role is significant during times of crisis where every single piece of information is invaluable and vital. However, Eric (2013) pointed out that Malaysian journalism is often underestimated, resulting in uncritical reporting and fewer concerns for investigative journalism.

In a study of investigative journalism in Malaysia, Norsiah et al. (2015) pointed out that investigative journalism in Malaysia is still in its infancy and that collective changes need to be made for improvement. The scholars opined that Malaysian journalists are "bound by ethics, rules, laws and regulations" (Norsiah et al., 2015, p. 638) that are claimed to protect national security. However, Turow (2014) defined this as circumstances that allow governments to censorships which limit the way of news reporting and writing.

In a study on the challenges faced by Malaysian journalists, Ismail et al. (2017) stated that journalism in the country is facing major external and internal challenges that could downplay their role as journalists. This includes the challenges of "lawsuit, information availability, issues availability, seeking the truth, weak enforcement and low impact". Additionally, they are also facing another eight newsroom challenges. This implies that Malaysian journalists may have an interest in investigative journalism, but state control and ownership restriction have undermined this interest, putting journalistic expression into silence.

Undeniably, the information system in the country is tied to the wider context which includes state practice. Many communication scholars have pointed out 
that, under different contexts of power, the general public does not always get access to information due to "corporatization", "commercialization", "commodification" and "concentration", where the news has become a product that is sold for profit (Wasko, 2014). Typical examples abound in Malaysia where journalists risk being arrested, detained, and even jailed on what the so-called powerful ruling class considers seditious and libellous publications. The detention of Malaysiakini journalists (Rodan, 2002) and the suspension of the licenses of Sarawak Report and The Edge for their coverage on the controversial government investment fund 1Malaysia Development (1MDB) (BBC News, 2016), and the closing down of The Malaysian Insider have been closely related to the unequal sharing of information in the country.

The MH370 incident has sparked more discussions on the roles of the Malaysian press and the degree of freedom it has in the coverage of crises, conflicts, and other issues that are of public concern. It is equally important to ascertain whether the press provides enough information for the people to react and respond whenever a crisis occurs. As stated by Hall (1990), access is not simple, it is an issue of how those in power form structures that define who regularly gets access and who should not reinforce the legitimacy of their interest and power. He further argued that the public generally does not have access to public debate. This assertion is particularly important during the $\mathrm{MH} 370$ crisis as people struggled over access to information that they deem relevant or significant. To counter these concerns, it is unavoidable to relate them to the wider Malaysian context that could intervene in the framing process.

\section{THEORETICAL FRAMEWORK}

\section{Framing}

Framing is an effective way to comprehend and understand media roles during any event or crisis. Mishra (2011, p. 24) stated that the "mass media set the frames of references that readers or viewers use to interpret and discuss public events". It organizes ideas that provide meanings in telling the audience what the problem of the crisis is or in short, it tells the essence of the issue. This is explained in detail by Entman (2004) that framing involves problem definition, causal interpretation, moral evaluation, and treatment recommendation which play a vital role in organizing ideas as well as shaping the news story while providing meaning to the news. Hence, the media frame can be very powerful and plays a critical role in shaping the public's understanding of the MH370 crisis. Audiences' attitudinal and behavioral reactions are influenced by the way news is being portrayed and framed (Temmerman, 2012).

Frame Building. Past studies have suggested that frame building is influenced by several factors. These include the impact of organizational restraints, the professional values of journalists, or their expectations about audiences' choice of news form and content. Akhavan-Majid and Ramaprasad 
(2000) allude to the roles of external factors such as the influence of ruling ideology in building news frames. The recent findings included the hierarchical influence mode of Shoemaker and Reese (2014). Basically, the scholars stated the five major factors in influencing news frames - the individual level, routine level, the organization level, social institution level, and social system level. On the other hand, Bruggemann (2014) theorizes factors at the micro level - the influence of individual (journalistic roles and working environment), meso level - the influence of organizational and professional (editorial policy and degree of freedom in writing news), and macro level - the influence of social institution and social system which may affect the news frames (state control and press freedom in the country context).

Frame Setting. Frame setting is a process that describes how news frames affect the audience. Entman (1993) mentioned that media frames could have an impact upon attitudes, opinions, or individual frames. News frames serve as schemata in telling people how to interpret certain events/ issues. In times of crisis, frame setting is crucial as it provides salience to the issue and how the audience should react and respond to the crisis. Kim et al. (2012) that understanding the public is important to develop an effective crisis strategy.

In the case of MH370, it is vital to understand how the crisis is framed. The publics' perception of a crisis is influenced by how it was portrayed or framed in the media (frame setting). According to Coombs and Holladay (2002), crisis events can be framed in different ways. The media may report the incident as preventable (humanerror accident), accidental (e.g. technical error), or unprecedented (e.g. natural disaster). The portrayal of a crisis provides cues to the way in which the public should perceive it and attribute crisis responsibility to the organizations or parties involved in the crisis. Coombs (2015) mentioned that the public attributes very little crisis responsibility to the victim cluster and low crisis responsibility to the accidental cluster. However, Schwarz (2012) pertinently pointed out that the public attributes a very strong crisis responsibility to the preventable cluster such as a crisis caused by human negligence. Therefore, frame setting would be investigated through interviewing journalists on the process of news gathering and writing in order to understand the news reporting of $\mathrm{MH} 370$.

\section{METHODS}

This study employed a qualitative method, using the in-depth interview as an instrument. According to Scheufele (2006) and Schostak (2006), the interview is a good method to discover the hidden meaning of issues related to the media. An interview could extend the conversation between people and it could provide in-depth information in answering the 'what' and 'how' of the issue.

In this study, eight journalists were interviewed (Table 1). The selection of journalists from both mainstream and alternative newspapers was based on 
Table 1

Profile of journalists

\begin{tabular}{lllc}
\hline & Gender & \multicolumn{1}{c}{ Medium } & Years of experience as a Journalist \\
\hline Journalist A & Male & Malaysiakini & 8 \\
Journalist B & Male & Malaysiakini & 11 \\
Journalist C & Male & The Star & 13 \\
Journalist D & Male & Harian Metro & 5 \\
Journalist E & Female & Harian Metro & 10 \\
Journalist F & Female & The Star & 6 \\
Journalist G & Female & Malaysian Insider & 8 \\
Journalist H & Female & Malaysian Insider & 14 \\
\hline
\end{tabular}

their circulation. The Star, Harian Metro, Malaysiakini, and The Malaysian Insider were chosen as they have the highest readership in 2014 when the crisis happened.

A pre-test of the interview questions was carried out, followed by the amendment of the interview questions to ensure validity. The snowball sampling technique was used, where the authors interviewed the first journalist, who then recommended other journalists to be interviewed. Before the interview, journalists were briefed and a consent form was signed in order to ensure that the interview process is accountable and that the identity of the journalists is kept confidential. The duration of the interview ranged from 30 minutes to 1 hour and 30 minutes. A recorder was used during the entire conversation. Later, the interview data were transcribed into text. The thematic analysis technique of Braun and Clarke (2006) was used in analyzing the data with the aid of NVivo 12 Pro software for data management, coding, sorting, and retrieval of data.

\section{FINDINGS AND ANALYSIS: JOURNALISTS' PERCEPTIONS}

In exploring journalists' experience in covering the MH370 crisis, the data were categorized based on the three main factors emphasized by Bruggemann (2014), which are: factors on the individual level, factors on the organizational and professional level, and factors on the state level.

\section{Individual Level Factor}

Personal Experiences and Knowledge. Describing the press conference during the first week of the incident, all the interviewees are of the view that the situation was merely chaotic and disorganized, with most of the journalists uncertain about what to do. They also noted that the situation worsened when media companies started sending their journalists to the suspected crash site in Vietnam, even when they were unsure of the truth of the matter.

For the whole week, we didn't know what is happening, we still don't know who established (was involved) and what is happening, 
there is no control over this incident, first week is very very chaotic.

Journalist B

One of the interviewees from mainstream newspapers mentioned that a lack of knowledge in the coverage of the aviation crisis posed double difficulties and challenges. The use of specific terms in describing the height and altitude of the plane makes it harder as local journalists who write the story seem not to understand the subject matter well.

You don't know much about plane, how it works, you don't know where the way point (direction of the plane), you don't know at what altitude the plane fly, whether it is 35000 feet, or going up. We were lacking knowledge in that particular area.

Journalist D

The interviewee went further to state that foreign media journalists have areas of specialties, adding that they also have access to the right sources such as Boeing Company and the aviation industry, noting that on the contrary, he does not think that there are Malaysian journalists who specialize in aviation reporting.

Maybe the foreign media have these sources (the access to the Boeing company) to tell what is happening. I think from what I understand; they are aerospace journalist. I don't think we have aerospace journalist in Malaysia. You know, here in Malaysia, journalists do everything.
They (foreign media journalist) just focus on specialized reporting.

Journalist D

\section{Organizational and Professional Levels factor}

Editorial Controls and Organization

Practice. The majority of the interviewees said that they have the freedom to write MH370 news stories, including but not limited to the angles of the news stories. However, they admitted that the final decision to publish is in the hands of the editor.

Our editor gave us full freedom, we just write whatever we could, because at the end of the day, they decide what should be published. We don't usually do stand-alone story. What happens is, when my colleague's story is similar to mine, we put them together, and that is how we work. But at the end of the day, the editor decides how much of the stories go in. But they told us to write everything, and just told us to write what we want to tell so that we can take it from there. So, in terms of writing restriction, I didn't feel anything.

Journalist $\mathrm{F}$

In sharing their opinions regarding rumors and speculations as well as the sensationalization of the MH370 incident, some interviewees said it is beyond the control of the journalists who wrote the stories. 
First of all, you have to understand the process, reporter writes the story, then we submit the story, sometimes someone might edit the story and the headline comes from the sub-editor, so it's not the journalist. So I (have to go through all the process). So you can blame the media, but not the journalist who did not come out with the headline. Sometimes the story you send might be changed, and it is done by the editor.

\section{Journalist D}

Nevertheless, one of the interviewees said that sometimes there is a need to sensationalize the news story in order to compete with other media. The journalist also noted that due to the restrictions on mainstream newspapers, critical viewpoints are censored and filtered by the editor before it gets published.

Of course, we need to sensationalize as we need to sell. I mean surely some people (some journalists) will blush (embarrass) by saying that the government is useless, that all wouldn't go through, or when the government is criticized for being incompetent and etc., they (the editor) will take that out.

Journalist D

\section{State-Level Factors}

Access to Source of Information. On access information, all the interviewees agreed that they refer to official sources
(Malaysian authorities) as their main source of information particularly through the press conference organized by the Malaysian authorities. This is because the authorities were the ones who were directly involved in the investigation of the incident.

We have a lot of press conferences, so most of the information we gathered are from the press conferences or authorities.

Quoted from Journalist E

However, it was not an easy task as all of them mentioned that the level of access to information was not sufficient. Some interviewees elaborated the situation in the press conferences, noting that many questions such as the shipment of mangosteen fruit despite it was being off-season were thrown to the Malaysian authorities but most were not answered. More often, replies were such that contains scanty information and leaves one in doubt as to what the facts are.

Basically, they didn't respond well to our questions, in the sense that, basically all the answers we got are, we are checking it, we are verifying it, we are investigating it, we will tell you when we get... and then they showed us the passengers, and the passengers'family, that's all. There was basically no clear-cut answer on what was happening in the first week.

Quoted from Journalist B 
Some interviewees alleged that authorities attempted to cover up, making it difficult for them to gather information, leaving questions unanswered.

Malaysian government was trying to cover up. First is regarding the cargo, it is something unusual for you to send the mangosteens at that time as it was not a season for mangosteens, until now no one could answer it. No one is willing (to answer), everyone tried to cover up and we don't know why they were covering up.

Quoted from Journalist E

One of the interviewees from a mainstream newspaper mentioned that the biggest challenge was verifying and confirming information.

I think the most difficult part is getting confirmation because there was only certain slot where the press conference was held, let's say 9 am in the morning. So if you miss the chance, which we will usually do, because there were so many people, where are we going to get the information? Nobody will talk to us because they were all afraid of gate order, for many authorities and police officials couldn't confirm things to us. We had to go through, say the press conference, or go through different people and a lot of time was wasted as they don't answer or we cannot reach them so getting confirmation was the most difficult.

Quoted from Journalist F

There were lots of rumors and speculations through social media, but there was no valid and reliable information to counter and curb them.

There were a lot of reports but they were either the same or doesn't make sense or lacking in details. We know the plane is missing, but we just don't know what happened and everyone keeps speculating.

Quoted from Journalist B

In response to the lack of access to information, most of the interviewees are of the view that the Malaysian government was trying to cover up. Therefore, in the quest to get enough information, many of them resorted to unofficial sources. The situation led to more confusion and rumors. This was mentioned by both mainstream and alternative newspapers interviewees:

Information is so scarce, a lot of media went to unofficial sources, that may or may not be reliable and some started having random conspiracy theories, and that received some level of publicity and we have to deal with that also.

Quoted from Journalist A

That's why when you don't have much information, you will write anything. That's why the foreign 
media like daily mail came out with ridiculous stories.

Quoted from Journalist D

On the news slant, interviewees from alternative newspapers stated that their critical position on issues regarding the MH370 is informed by the fact that they have more freedom to report the news. This freedom according to them stems from the fact that quite unlike the mainstream newspapers, alternative online newspapers in Malaysia do not require to apply for a permit from Malaysia's Ministry of Home Affairs to start an online news portal.

Sometimes the government doesn't feel right to review certain things because they were afraid of the backlash. Sometime when you are lucky, you will get insight stories, but those with the mainstream are not able to write certain things, it will make the government look bad, so when it comes to freedom of speech, in terms of writing, they are not free. News portal like kini (Malaysiakini), Malaysian Insight, we cannot say that we are totally free, but we were able to put it out as it is, without having to bow to anyone. We (alternative media) are not answerable to government, but the mainstream newspapers like NST, The Star or The Sun, to certain extent, they have to.

Quoted from Journalist H

On the contrary, interviewees from the mainstream newspapers were restricted on what to write and the slant to adopt in writing the stories.

That's why most of the local journalists slowed down as we were given warning by the government. There were restrictions as we were stopped by Hishammuddin (Acting Transport Minister at the time) as he asked 'are you going to tarnish country's reputation?' Don't ask that kind of question, stop! so we cannot basically couldn't write much.

Quoted from Journalist C

Although journalists from the alternative newspapers provided a more critical news report, yet it does not mean that they had no limitations. Their restrictions came in the form of regulations as well as the country's practice. They were labeled antagonists or the hot style media that could threaten the powerful ruling, and are usually barred from entering the Prime Minister's Office and UMNO headquarter. On reasons for the barring of journalists from alternative newspapers from entering the Prime Minister's office, one of the interviewees stated that the Malaysian authorities are not usually comfortable with probing questions from this group of journalists-

\section{DISCUSSIONS}

The news frame in the coverage of the MH370 crisis was greatly influenced by both internal and external factors, including the influence of individuals, the influence of media organisations, and state practice. As 
remarked by most of the interviewees, lack of experience and knowledge in covering the aviation crisis posed double challenges in the coverage of the MH370 crisis. This lack of training and specialization in aviation reporting and experience are the individual factors that led to uncritical analysis and lack of in-depth reporting on the MH370 crisis. This is cited in Rao (2018) that one of the factors that lead to the decline of media credibility is the lack of investigative and meaningful journalism.

Even though most of the journalists stated that they have the freedom to decide the news angle, however, they admitted that the final output is usually decided by the editor or editor-in-chief. This finding is in line with Hanggli (2012) who mentioned that the power of an organization is defined as having influence in the background or/and in the foreground. Thus, media frames are often interrupted by the frame builder which includes the news editor. It also corroborates Rita (2012) who further mentioned that "management has a legal responsibility to serve the economic interest of owners", therefore as a part of the media company, journalists tend to self-censor as there are always unspoken rules which indirectly control or influence the way a story is framed and covered. Under pressure, journalists may attempt to frame a story in a way that is more favorable or beneficial to their organization, company, or superior.

Additionally, this is also mentioned in Yang and Md. Sidin (2015) study that gatekeeping processes could happen at the individual, routine and organizational as well as at institutional levels. They further stated that ownership often influences the gatekeeping process of newspapers in their reporting of interethnic conflicts. The gatekeeping process of newspapers has often been closely connected to political factors, which has had negative impacts on practicing the freedom of news writing and reporting. Also, it was found out in the study that though some journalists in the country believed that the emergence of new media has offered some hope to re-balance the power between the powerful ruling and journalists, however, the Internet is increasingly subjected to government control. This is evident in this study that alternative media such as Malaysiakini and Malaysian Insider have often been clamped down by the government. The journalists from both news media have pointed out that they are often suppressed and have been labeled as "anti-government". This undermined what they can achieve in their watchdog role. A typical example was when they were not allowed to attend the UMNO headquarters' meeting or interview the Prime Minister.

Hence, this study observed that the political climate in Malaysia often serves as a stumbling block to the development of a free press in the country. Jan et al. (2017) pointed out that journalists are increasingly dependent on official sources in news writing due to the increasing deadline pressures. This study found that both mainstream and alternative newspaper journalists usually refer to official sources or official press conferences for information. 
Powerful institutional actors such as the government and authorities featured more in the MH370 stories compared to other actors such as professionals or experts. This is in-line with the numerous researchers who have pointed out that news source is related to the power issue as sources lead the dance in the selected phrase. This is also proven in Hänggli and Kriesi (2010) study that political actors significantly influence media frames by taking the lead in frame building. Bruggemann (2014) pertinently pointed out that journalists practice frame sending by reproducing the powerful ruling agenda due to the power controls and restrictions imposed on the journalist. In other words, adopting similar sources in reporting the MH370 crisis implies that the news is written from a similar angle or perspective which could be biased as no equal news spaces were given to various sites. On the other hand, the powerful ruling has the greatest power to decide the content of news which is often beyond the journalist's control.

In addition, all the interviewees claimed that the main official sources have neither provided enough nor confirmed information to the journalists. The delayed, unconfirmed and unverified information resulted in lots of confusion. Consequently, a lot of rumors and speculations were spread through social media. Citizens, as well as journalists, developed conspiracy theories in analyzing the cause of the MH370 incident. This was shown in The Star's (2014) headline "Missing MAS flight: Don't share unverified info". Besides, anti-fake news was launched recently to curb the dissemination of fake news (The Straits Times, 2018).

Furthermore, the Malaysian law which is seen as a top-down instrument by giving enormous power to the state to dominate and control the crisis situation (Balasubramaniam, 2012) has impacts on practicing democracy and human rights for accessing information during a crisis. For instance, the authority may invoke the presumption to legitimize their interest and power by asserting the ideas that people should obey the law to avoid the danger of chaos, in order to delegitimize the counterhegemonic. The government has a history of classifying any document or information as top secret, confidential or restricted and an offense under the Official Secret Act 1972 (OSA) of exposing them is punishable by law (Faisal, 2015). One such example is the case of politician Rafizi Ramli who according to The Sun Daily (2016) was charged under the OSA for allegedly releasing classified information on the 1Malaysia Development Berhad (1MDB) scandal which was a global web of fraud and corruption that involved the former prime minister Najib Razak (BBC News, 2020).

This study is never just about the Malaysian media, but also media issue which is often raised at the global level. This is highlighted in Lee and Baek (2018) and Zelizer (2015) studies that journalists often neutralize and legitimize the rights of the powerful elites. Obviously, journalists are trapped in power relations and this leads to a similar pattern of reporting. This study, therefore, argues that Malaysian media 
appears to have failed to play its role as a repository of information and surveillance to the society during the MH370 crisis simply because the centralization of power has stifled the mainstream media and blocked the fourth estate from serving as effective checks-and-balances on the powers that be.

In summary, the main challenge in the case of the MH370 crisis is the lack of access to information and the inconsistencies that characterize the available information.

The study of the MH370 disappearance is not without limitations. The interview focused only on the perspective of journalists. The victims' families \& friends' perspectives towards access to information during the crisis may as well be explored by future studies. Nevertheless, this study furthers a scholarly understanding of how Malaysian journalists frame and report crisis and more significantly is that crisis frame is not solely dependent on the journalist who writes the stories, but it is always influenced by several internal and external factors.

It should be noted that the turbulent political environment, which includes the resignation of former Prime Minister Mahathir Mohamad, the current practices governed by Prime Minister Muhyiddin Yassin as well as multiple political instabilities, does not open up the prospect of further freedom of expression and freedom of the press in the country.

\section{CONCLUSION}

This study contributes new knowledge as most MH370 studies either focused on crisis communication and crisis management
(Junaidi et al., 2014; Kalthom et al., 2014; Lee \& Han, 2014; Peiter, 2014) or content analyses of MH370 related news (Bier et al., 2017; Park et al., 2016). However, how journalists perceive the coverage of the crisis is rarely highlighted. In a nutshell, this study could help in understanding information subsidies during an international crisis and how it relates to the wider context of power.

In addition, the MH370 crisis seemed to have portrayed the country as one that lacks a crisis communication plan. The findings of this study show that there is no consistency in the information disseminated to the journalists. The interviews with journalists reveal that they face challenges in accessing information due to a lack of press freedom. Therefore, this research can act as a catalyst for the government of Malaysia to not only improve its crisis communication plan but also to give journalists more freedom in doing their job.

Furthermore, this study emphasizes the importance of having good coordination and communication during a crisis, particularly in handling press conferences and dealing with journalists. The findings of this study echoed the recommendations of the Malaysian ICAO and Nabil et al. (2019) of providing an effective Emergency Response Plan to tackle potential aviation crises. Improving the cooperation between several key parties is necessary in order to prevent the sharing and reporting of conflicting information. The parties include the Aircraft Communications Addressing and Reporting Systems (ACARS), International Civil Aviation Organization (ICAO), Malaysia 
Airlines Berhad (MAS), Royal Malaysian Air Force (RMAF), and the Malaysian government. The information delivered to external parties and the public must be verified carefully before it is published or distributed to external parties or journalists. In addition, more detailed evaluation and risk management exercises which include crisis communication to familiarize those involved with the Emergency Response Plan when it comes to tackling an unexpected crisis are encouraged. Peiter (2014) pointed out that a contingency plan was only introduced in August 2014, four months after the MH370 tragedy occurred. In short, it is vital to have an effective ERP as many aviation crises are characterized by "the suddenness and fatal consequences of the triggering event" that require an airline's immediate reaction and a high degree of contact with stakeholders (Henderson, 2003, p. 285). A well-established ERP is helpful to organizations such as MAS in managing crisis communication which includes dealing with journalists as well as in ensuring an effective process of the dissemination of crisis information.

\section{ACKNOWLEDGEMENT}

All authors have contributed to the research equally in terms of data collection, knowledge sharing, and editing of the manuscript. All authors have no conflict of interest.

\section{REFERENCES}

Akhavan-Majid, R., \& Ramaprasad, J. (2000). Framing Beijing: Dominant ideological influences on the American press coverage of the Fourth UN Conference on women and the NGO Forum. Gazette, 62(1), 45-59. https://doi. org/10.1177/0016549200062001004

Balasubramaniam, R. R. (2012). Hobbism and the problem of authoritarian rule in Malaysia. Hague Journal on the Rule of Law, 4(2), 211-234.

BBC News. (2014, March 16). Missing Malaysia plane: Malaysia requests countries' help. https:// www.bbc.com/news/world-asia-26600361

BBC News. (2016, September 28). MH17 Ukraine plane crash: What we know. https://www.bbc. com/news/world-europe-28357880

BBC News. (2020, October 22). Goldman Sachs to pay \$3bn over 1MDB corruption scandal. https:// www.bbc.com/news/business-54597256

Beh, Y. H. (2018, August 4). Continue search for MH370. The Star. https://www.thestar. com.my/news/nation/2018/08/04/continuesearch-for-mh370-many-questions-are-still-leftunanswered-say-kin-of-chinese-victims/

Bier, L. M., Park, S., \& Palenchar, M. J. (2017). Framing the flight MH370 mystery: A content analysis of Malaysian, Chinese, and U.S. media. International Communication Gazette, 80 (2), 158-184. https://doi. org/10.1177/1748048517707440

Braun, V., \& Clarke, V. (2006). Using thematic analysis in psychology. Qualitative Research in Psychology, 3(2), 77-101. https://doi. org/10.1191/1478088706qp063oa

Bruggemann, M. (2014). Between frame setting and frame sending: How journalists contribute to news frames. Communication Theory, 24(1), 61-82.

Coombs, W. T. (2015). Ongoing crisis communication: Planning, managing, and responding (4th ed.). SAGE.

Coombs, W. T., \& Holladay, S. J. (2002). Helping crisis managers protect reputational assets: Initial 
tests of the situational crisis communication theory. Management Communication Quarterly, 16(2), 165-186. https://doi.org/10.1177/ 089331802237233

Daily Mail Online. (2015, February 12). Chinese relatives protest in Malaysia over MH370. http:// www.dailymail.co.uk/wires/afp/article-2950293/ Chinese-relatives-protest-Malaysia-MH370.html

Entman, R. M. (1991). Framing U.S. coverage of international news: Contrasts in narratives of the KAL and Iran air incidents. Journal of Communication, 41(4), 6-27. https://doi. org/10.1111/j.1460-2466.1991.tb02328.x

Entman, R. M. (1993). Framing: Toward clarification of a paradigm. Journal of Communication, 43(4), 51-58. https://doi.org/10.1111/j.1460-2466.1993. tb01304.x

Entman, R. M. (2004). Projections of power: Framing news, public opinion, and U.S. foreign policy. University of Chicago Press.

Eric, L. (2013). Bridging the cultural gaps in journalism training and education in Asia. Konrad-Adanauer-Stiftung Media Asia Programme. https://ro.uow.edu.au/cgi/viewcontent.cgi?referer $=\&$ httpsredir $=1 \&$ article $=1668 \&$ context $=1$ hapapers

Faisal, A. A. M. (2015, July 30). Whistleblowers unprotected under WPA? Malaysiakini. https:// www.malaysiakini.com/letters/306738

Filippini, M. (2017). Using Gramsci: A new approach. Pluto Press.

Rodan, G. (2002). The implication of the Asian crisis for media control in Asia in reconfiguring East Asia regional institutions and organisations after the crisis. Routledge Curzon Press.

Gavin, H. (2018, May 4). MH370: Pilot deliberately avoided detection and flight disappearance was a criminal act. Express. https://www.express.co.uk/ news/world/959577/mh370-malaysia-airlinesmissing-plane-what-happened-mh370
Hall, S. (1990). Stuart Hall's theory of ideology: A frame for rhetorical criticism. Western Journal of Speech Communication, 54(4), 495-514. https:// doi.org/10.1080/10570319009374357

Hanggli, R. (2012). Key factors in frame building: How strategic political actors shape news media coverage. American Behavioural Scientist, 56(3), 300-317. https://doi.org/ $10.1177 / 0002764211426327$

Hänggli, R., \& Kriesi, H. (2010). Political framing strategies and their impact on media framing in a Swiss direct-democratic campaign. Political Communication, 27(2), 141-157. https://doi. org/10.1080/10584600903501484

Henderson, J. C. (2003). Communicating in a crisis: Flight SQ 006. Toursim Management, 24(3): 279-287. https://doi.org/10.1016/S02615177(02)00070-5

Hout, T. V., \& Macgilchrist, F. (2012). Framing the news: An ethnographic view of business news writing. Text \& Talk, 30(2), 169-191. https://doi. org/10.1515/text.2010.009

Ismail, A., Mohd, K. A., \& Mustaffa, C. S. (2017). Investigative journalism in Malaysia: The battle between outside and inside newsroom challenges. International Conference on Communication and Media: An International Communication Association Regional Conference, 33, 00079. https://doi.org/10.1051/shsconf/20173300079

Jacques, T. (2014). Issue and crisis management: Exploring issues, crises, risk and reputation. Oxford University Press.

Jan, B., Anna, B., Leen, H., \& Baldwin, V. G. (2017). The News is in the frame: A journalist-centered approach to the frame-building process of Belgian Syria fighters. Journalism, 18(3), 298316. https://doi.org/10.1177/1464884915610988

Junaidi, A. B., Sahandri, G. B. H. M., \& Mazura, M. M. (2014). Crisis management - Malaysian aviation tragedies. In Multidisciplinary academic 
research (pp. 77-93). https://globalilluminators. org/

Kalthom, H., Aida N. A., Mastura, I., Fauzi, K. M., Anidah, R., Mohaida, M., \& Najmuddin, S. H. S. (2014). A preliminary study on effects of social media in crisis communication from public relations practitioners' views. Social and Behavioural Sciences, 155(6), 223-227. https:// doi.org/10.1016/j.sbspro.2014.10.283

Kim, J., Kim, H. J., \& Cameron, G. T. (2012). Finding primary publics: A test of the third-person perception in corporate crisis situation. Journal of Public Relations, 24(5), 391-408. https://doi. org/10.1080/1062726X.2012.723275

Koselleck, R. (2006). Crisis. Journal of the History of Ideas, 67(2), 357-400.

Lee, N. Y., \& Baek, K. (2018). Squeezing out economic news for business news? Changes in economic journalism over the past 20 years in South Korea. Journalism, 19(9-10), 1220-1238. https://doi.org/10.1177/1464884916665403

Lee, C., \& Han, L. (2014). Faith-based organizations and transnational voluntarism in China: A case study on Malaysia airline MH370 incident. Voluntas: International Journal of Voluntary and Nonprofit Organizations, 20(4), 319-350. https:// doi.org/10.1007/s11266-014-9518-2

Li, C. W., Phun, V. K., Suzuki, M., \& Yai, T. (2015). The effects of aviation accidents on public perception toward an airline. Journal of the Eastern Asia Society for Transportation Studies, 11, 2347-2362. https://doi.org/10.11175/ easts. 11.2347

Mishra, N. (2011). Power to define: Framing of naxalites in the Indian media. GMJ: Mediterranean Edition, 6(2), 23-35.

Nabil, S. A., Asraf, A. S. M., \& Jamaludin, I. (2019). The case study of emergency plan (ERP) implementation during the Malaysia Airlines
(MAS) Flight MH370 disappearance. Malaysian Journal of Computing, 4(2), 270-277. https://doi. org/10.24191/mjoc.v4i2.4809

Norsiah, A. H., Sobhi, I. M., \& Nazialita, G. M. (2015). Empowering citizen media through investigative journalism in Malaysia. Malaysian Journal of Communication, 3(2), 631-647. https://doi.org/10.17576/JKMJC-2015-3102-36

Park, S., Bier, L. M., \& Palenchar, M. J. (2016). Framing a mystery: Information subsidies and media coverage of Malaysia airlines flight 370. The International Communication Gazette, 42(4), 654-664. https://doi. org/10.1177/1748048517707440

Peiter, N. (2014). The two Malaysia airlines disasters in 2014: Lessons for airline management in a global context [Paper presentation]. The World Business, Finance and Management Conference, Auckland New Zealand. https:// unitec.researchbank.ac.nz/handle/

Randall, L. (2018, October 27). MH370 bombshell: Author says he knows doomed plane's exact location. Express. https://www.express.co.uk/ news/world/1037204/MH370-news-locationmissing-plane-malaysia-airlines-flight

Rao, S. (2018). Awakening the dragon's and elephant's media: Comparative analysis of India's and China's journalism ethics. Journalism, 19(9-10), 1275-1290. https://doi. org/10.1177/1464884916670669

Rita, C. (2012). Shaping and cutting the media agenda: Television reporters' perceptions of agenda- and frame-building and agenda-cutting influences. Journalism \& Communication Monographs, 14(2), 85-146. https://doi. org/10.1177/1522637912444106

Romantan, A. (2005). The social amplification of commercial aviation risks: A longitudinal analysis of media effects on air travel behavior [Paper presentation]. International 
Communication Association Conference, New York, USA. http://195.130.87.21:8080/dspace/ handle/123456789/75

Sankaran, R. (2016). Cross-cultural perspectives and influences in reporting airline disasters: The MH370 episode. Journal of Media Asia, 43(1), 23-34. https://doi.org/10.1080/01296612.2016 .1169692

Scheufele, B. (2006). Frames, schemata, and news reporting. Communications, 31(1), 65-83. https://doi.org/10.1515/COMMUN.2006.005

Schostak, J. F. (2006). Interviewing and representation in qualitative research. Open University Press.

Schwarz, A. (2012). How publics use social media to respond to blame games in crisis communication: The love parade tragedy in Duisburg 2010. Public Relations Review, 38(3), 430-437. https:// doi.org/10.1016/j.pubrev.2012.01.009

Secret China Online News. (2014, May 2). Mǎláixīyà shǒu dù gōngbù MH370 shī lián chūbù bàogào (tú) [Malaysia announces a preliminary report on the loss of MH370 for the first time]. Vision Times. http://www.secretchina.com/ news/14/05/02/539320.html?

Seeger, M. W., Sellnow, R., \& Ulmer, R. R. (2003). Communication and organizational crisis. Praeger.

Seon-Kyoung, A., \& Karla, K. G. (2009). How do the news media frame crises? A content analysis of crisis news coverage. Public Relations Review, 35(2), 107-112. https://doi.org/10.1016/j. pubrev.2009.01.010

Shoemaker, P. J., \& Reese, S. D. (2014). Mediating the message in the 21st century: A media sociology perspective (3rd ed.). Routledge.

Sorensen, C. (2014, March 21). How Flight MH370 could vanish without a trace. Macleans. https:// www.macleans.ca/news/world/how-an-airplanecan-vanish-without-a-tracel
Temmerman, M. (2012). Naming and framing in Belgian politics. An analysis of the representation of politicians and the political state of affairs during the 2007 government formation period in the Belgian press. Belgian Journal of Linguistics, 24(1), 120-138. https:// doi.org/10.1075/bj1.24.06tem

The Star. (2014, March 9). Missing MAS flight: "Don't share unverified info". https://www. thestar.com.my/News/Nation/2014/03/09/Dontshare-unverified-info

The Straits Times. (2018, April 2). Malaysia passes anti-fake news bill. http://www.straitstimes. com/asia/se-asia/malaysia-votes-in-anti-fakenews-law

The Sun Daily. (2016, April 8). Refizi charged for violating Official Secrets Act 1972. http://www. thesundaily.my/news/1754831

Turow, J. (2014). Media today: An introduction to mass communication (5th ed.). Routledge.

Utusan Online. (2015, January 29). MH370 diisytihar kemalangan, 239 penumpang dan kru dianggap terkorban [MH370 was declared an accident, with 239 passengers and crew members presumed dead]. http://www.utusan.com. my/berita/nahas-bencana/mh370-diisytiharkemalangan-239-penumpang-dan-kru-dianggapterkor ban-1.53972

Wasko, J. (2014). The study of the political economy of the media in the twenty-first century. International Journal of Media \& Cultural Politics, 10(3), 259-271. https://doi.org/10.1386/ macp.10.3.259_1

Yan, Y., \& Kim, Y. (2015). Framing the crisis by one's seat: A comparative study of newspaper frames of the Asiana crash in the USA, Korea, and China. Asian Journal of Communication, 25(5), 1-21. https://doi.org/10.1080/01292986. 2014.990470 


\section{Framing OF MH370 Crisis}

Yang, L. F., \& Md. Sidin A. I. (2015). Gatekeeping in the coverage of interethnic conflicts: An analysis of mainstream and alternative newspapers in Malaysia. SEARCH, 7(1), 23-51.
Zelizer, B. (2015). Terms of choice: Uncertainty, journalism, and crisis. Journal of Communication, 65(5), 888-908. https://doi.org/10.1111/ jcom. 12157 
